
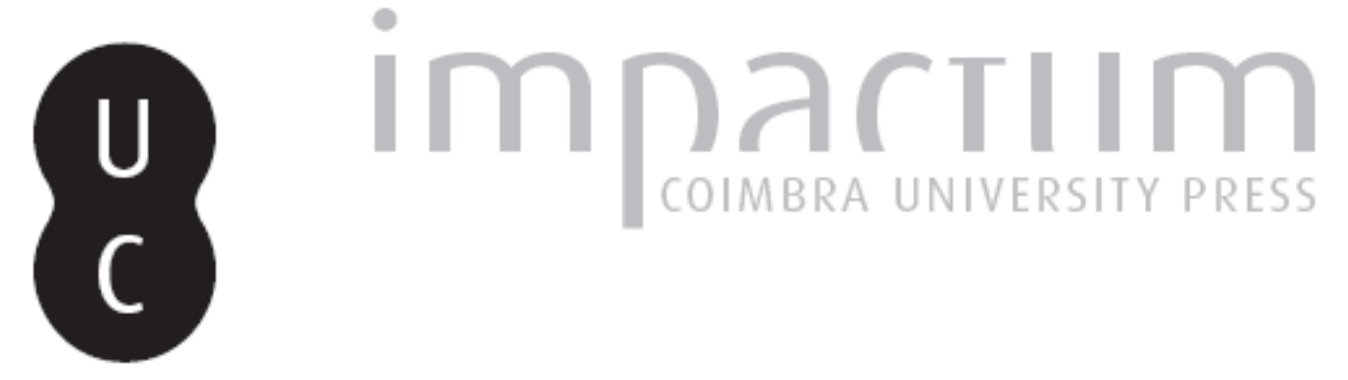

\title{
O complexo totalizante simbólico: religião popular, xamanismo e psicanálise nos arquivos da Inquisição portuguesa
}
Autor(es):
Ribeiro, António Vitor Sanches Ferreira
Publicado por: Centro de História da Sociedade e da Cultura
URL
persistente:
URI:http://hdl.handle.net/10316.2/39578
DOI:
DOI:http://dx.doi.org/10.14195/1645-2259_9_3

Accessed : $\quad$ 26-Apr-2023 10:44:05

A navegação consulta e descarregamento dos títulos inseridos nas Bibliotecas Digitais UC Digitalis, UC Pombalina e UC Impactum, pressupõem a aceitação plena e sem reservas dos Termos e Condições de Uso destas Bibliotecas Digitais, disponíveis em https://digitalis.uc.pt/pt-pt/termos.

Conforme exposto nos referidos Termos e Condições de Uso, o descarregamento de títulos de acesso restrito requer uma licença válida de autorização devendo o utilizador aceder ao(s) documento(s) a partir de um endereço de IP da instituição detentora da supramencionada licença.

Ao utilizador é apenas permitido o descarregamento para uso pessoal, pelo que o emprego do(s) título(s) descarregado(s) para outro fim, designadamente comercial, carece de autorização do respetivo autor ou editor da obra.

Na medida em que todas as obras da UC Digitalis se encontram protegidas pelo Código do Direito de Autor e Direitos Conexos e demais legislação aplicável, toda a cópia, parcial ou total, deste documento, nos casos em que é legalmente admitida, deverá conter ou fazer-se acompanhar por este aviso.

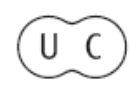



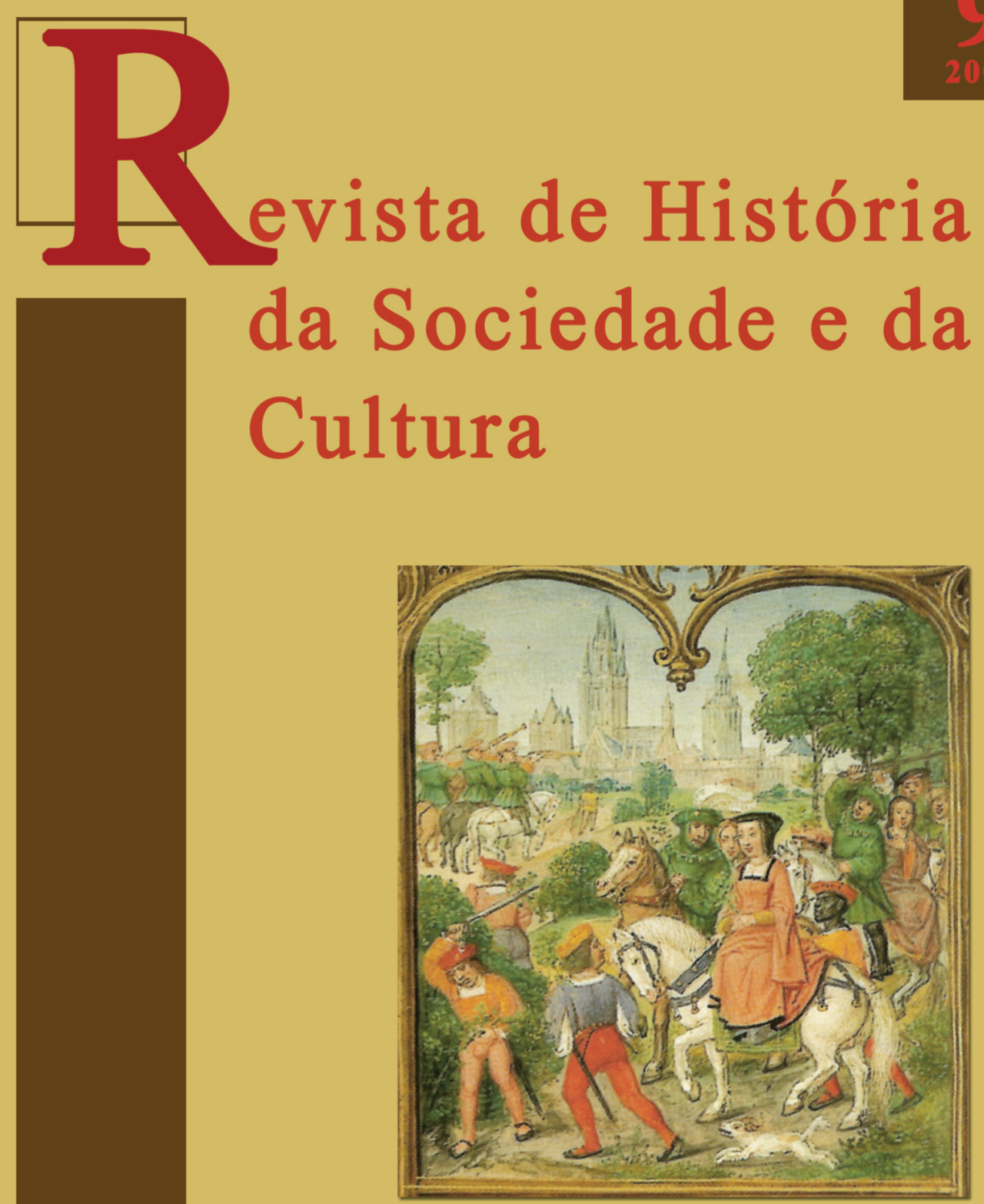

Centro de História da Sociedade e da Cultura Universidade de Coimbra

Coimbra 


\title{
O complexo totalizante simbólico: religião popular, xamanismo e psicanálise nos arquivos da Inquisição portuguesa
}

\author{
António Vitor Sanches Ferreira Ribeiro \\ Doutorando na Universidade de Coimbra \\ avs.ribeiro@gmail.com
}

Texto entregue em/Text submited on: 10/05/2009

\section{Resumo/Abstract:}

Este trabalho pretende desenvolver uma hipótese colocada na dissertação de doutoramento intitulada $O$ Auto dos místicos, na qual se evidenciaram os aspectos ligados a uma mitologia astral dualista, de fundo xamânico, existentes no imaginário místico português. Esta cosmovisão assentava num movimento triádico dialéctico, cujo funcionamento é generalizável ao universo físico e metafísico. Assim, todos os aspectos da vida, principalmente os que estão ligados à relação entre mortos e vivos, se materializavam em figuras simbólicas. Estes símbolos, presentes numa área que extravasa o contexto português e europeu, determinaram comportamentos, rituais ou sonhos, presentes na cultura e religiosidade populares, como a licantropia e o transe. A não consideração ou desvalorização dos aspectos referidos levou a que autores ligados à psicanálise e à antropologia, como Lévi-Strauss, Freud ou Jung, tivessem uma visão distorcida ou reduzida dessas manifestações.

This study envisages developing further the hypothesis introduced in the Phd dissertation O Auto dos místicos, which outlined the features of a dualist astral mythology, of shaman provenance, prevailing in Portuguese mythical imagery. This cosmic vision was based on a triadic dialectic movement, which applies to both the physical and metaphysical universe. Therefore, all aspects of life, particularly those concerned with the relations between the living and the dead, were materialised in symbolic figures. Such symbols, which were not peculiar to Portugal or even Europe, influenced behaviours, rituals and dreams, present in the culture and religiousness of the people, such as lycanthropy and trance. By disregarding or underestimating this, authors like Lévi-Strauss, Freud or Jung, who were linked to psychoanalysis and anthropology, adopted distorted or narrow views of such manifestations.

Palavras chave/Key words:

Religião popular; Inquisição; Licantropia; Xamanismo, Psicanálise.

Popular religion; Inquisition; Lycanthropy; Shamanism, Psychoanalysis 


\section{Introdução}

Num trabalho recente sobre as fontes do imaginário místico português na Época Moderna, tive a oportunidade de ensaiar uma perspectiva sistematizadora do universo mental que subjaz à religiosidade popular em Portugal ${ }^{1}$. Este artigo, de algum modo pretende ser a continuação dessa pesquisa. De forma sucinta, e para o que aqui interessa, as ideias expostas nesse texto foram:

- O misticismo português, cujo período de gestação atravessou todo o século XVI, construiu-se a partir da influência de duas tradições distintas. Uma, mais recente, resultante da emergência de uma sensibilidade religiosa centrada no interiorismo místico, um paradigma que se impôs de forma categórica na Espanha dos séculos XV e XVI. A outra, sobre a qual me irei deter neste artigo, corporizava uma cosmovisão ancestral, pré-cristã, que tinha como matriz uma perspectiva dualista, moldada à imagem dos movimenos astrais do Sol e da Lua.

- Esse dualismo implicava uma forma dialéctica de pensar a realidade, em termos muito semelhantes à que Hegel utilizou. A relação entre os opostos supunha três termos, dois antitéticos e um terceiro, a síntese, que estabelecia a mediação entre os outros dois. De forma concreta, e em relação à religiosidade popular, referi a oposição entre o Céu e a Terra e a forma como estes dois termos continham, por sua vez, uma luta de opostos no interior de cada um deles.

- Na Terra essa oposição manifestava-se sob a forma de aparições de moiras, divindades subterrâneas herdadas de um passado pré-cristão. A mitologia concebia-as em forma de tríades: uma anunciava a fortuna, outra a desgraça e a terceira fiava no seu tear, incessantemente, o destino. Foi ainda visto que estas divindades, frequentemente referidas como "senhoras", surgiam vestidas de branco ou negro, consoante anunciassem fortuna ou desgraça. No Céu, por seu turno, a luta era entre astros ou animais,

1 RIBEIRO, António Vitor - O Auto dos místicos. “Alumbrados”, profecias, aparições e inquisidores (séculos XVI-XVIII). Coimbra: Faculdade de Letras da Universidade de Coimbra, 2009 (dissertação de doutoramento em História Moderna, policopiada). 
uns brancos outros negros. Ocasionalmente, o Sol surgia sob a forma de tríade: três círculos solares no interior de outro círculo solar maior.

- A semelhança entre a filosofia hegeliana e estas manifestações pareceume pertinente. Hegel construíra as fundações da sua filosofia com base na mística alemã medieval, nomeadamente a partir das formulações de Eckhart ${ }^{2}$. Estas, por sua vez, fundavam-se numa teologia negativa e dialéctica, em que a medida de Deus é dada pelo homem. Deus deve, portanto, alienar-se, transformar-se no seu oposto, encarnar, para depois voltar a si, auto-consciente da sua condição divina. Tive também a oportunidade de colocar em evidência os pontos de contacto entre a doutrina de Eckhart e o gnosticismo dos primeiros séculos do cristianismo. Foi ainda possível identificar vestígios desse gnosticismo, existentes numa profecia denunciada à Inquisição portuguesa. Na perspectiva gnóstica, havia um conjunto de partículas de luz, de origem divina, que ficavam aprisionadas na matéria. Por um impulso irresistível, elas teriam tendência a voltar à unidade luminosa original, escapando à diversidade da matéria. Uma outra forma de colocar a questão trata-se da passagem do uno original, indiferenciado e imaterial, para o seu oposto, a diversidade da matéria, regressando ao uno original, mas desta vez com um sentido de absoluto que lhe é conferido pela sua antítese. Em qualquer dos casos, estamos perante um percurso triádico que termina num processo unitivo ${ }^{3}$.

2 Ver BENZ, Ernst - Les sources mystiques de la philosophie romantique allemande. Paris: J.Vrin, 1968. Também Kuno Francke afirmou, sobre a mística de Eckhart, que "é uma clara antecipação do princípio hegeliano do auto-desenvolvimento da Ideia", ver FRANCKE, Kuno - Mediaeval German Mysticism. The Harvard Theological Review, 5 (1912) 113.

3 Sobre uma certa homogeneidade da experiência unitiva, da multiplicidade para a indistinção, através de uma abordagem comparativa entre três textos de épocas diferentes, que vão do mundo Védico a Aldous Huxley, passando por Eckhart, será útil consultar MELCHERT, Norman - Mystical Experience and Ontological Claims. Philosophy and Phenomenological Research, 37 (1977) 445-463. O esquema ternário aparece formulado de forma clara por Eckhart num dos seus sermões: "é necessário que todas as coisas sejam banhadas no sangue de Cristo e voltem ao Pai através da mediação do Filho, da mesma forma que o Pai faz todas as coisas pela mediação do Filho", citado em COLLEDGE, Edmund; McGINN, Bernard (trad. e introd.) - Meister Eckhart: the Essential Sermons, Commentaries, Treatises and Defense. Mahwah: Paulist Press, 1981, p. 30. A Santíssima Trindade é um dos símbolos mais fortes deste processo triádico, o que talvez explique a centralidade que o dogma da Trindade assume no gnosticismo cristão, ver o capítulo "Les voies de la Gnose" em DECRET, François - L'Afrique Manichéenne (IVe-Ve siècles). Étude historique et doctrinale. Paris: Études Augustiniennes, 1978, em particular as p. 261-262; DECRET, François - Aspects 
- O misticismo espanhol, forjado no século XVI, tem as suas raízes na mística medieval, nomeadamente alemã e flamenga ${ }^{4}$. $\mathrm{O}$ autor que inaugurou a literatura mística em Espanha, Francisco de Osuna, fala do mesmo processo unitivo, através da prática do recogimiento, no qual o objectivo era "unir o que estava disperso". Ou seja, passar da diversidade desconcertante da matéria para a unidade da alma com Deus. No seu Abecedario espiritual, Osuna utiliza a metáfora uterina para definir o processo de morte e renascimento que permitirá o referido processo ${ }^{5}$. No meu texto tive a oportunidade de demonstrar que o processo de Osuna era uma cristianização de um conjunto de práticas derivadas do xamanismo eurasiático, e que a metáfora uterina estava ligada a uma sexualização (feminilização) da Terra, em que esta funcionava como polo oposto do Céu (masculinizado). Por esta via pode-se, por um lado, estabelecer uma ligação entre o "complexo arcaico" e o misticismo moderno, e, por outro, verificar que o terreno comum entre todos os aspectos referidos assenta nesta perspectiva tríplice de pensar a realidade.

Nas páginas que se seguem tentarei demonstrar três propostas:

a) a visão triádica da realidade é absoluta, não serve apenas para a oposição entre Céu e Terra, matéria e espírito, etc., mas para todas as facetas do universo, entendido no seu sentido mais amplo, físico e metafísico;

b) esta visão dialéctica é inerente ao real, impõe-se ao espírito humano e este, por sua vez, aplica-o novamente através da utilização de símbolos,

du Manichéisme dans l'Afrique Romaine. Les controverses de Fortunatus, Faustus et Felix avec saint Augustin. Paris: Études Augustiniennes, 1970, p. 225. Ainda sobre a centralidade do pensamento triádico em grupos gnósticos ver GARDNER, Iain; LIEU, Samuel N. C. (eds.) - Manichaean Texts from the Roman Empire. Cambridge: University Press, 2004, p. $12-13$.

${ }^{4}$ Osuna bebeu as suas influências, em grande medida, na literatura mística flamenga, ver GROULT, Pierre - Les Mystiques des Pays-Bas et la Littérature Espagnole du Seizième Siècle. Louvain: Librairie Universitaire, 1927, em especial o capítulo "La littérature des Pays-Bas et les origines du mysticisme espagnol 1475-1550", p. 80-91. Por seu lado, Menendez Pelayo afirmou que "quem trabalhe para a história da nossa mística terá de fixar, antes de mais, o seu olhar na remota época da influência alemã", citado em MARTÍN, Teodoro - Enrique Herp (Harphius) en las letras españolas. Verdad y Vida. 117 (1972) 427. Esta influência do Norte no misticismo espanhol é, contudo, contestada por NIETO, José - El carácter no místico de los Alumbrados de Toledo, 1509(?)-1524 in ALCALÁ, Ángel - Inquisición Española e mentalidad inquisitorial. Barcelona: Ariel, 1984, p. 410-423.

5 Ver RIBEIRO, António - O Auto dos místicos..., cit., p. 363-364. 
num conjunto coerente, a que darei o nome de "complexo totalizante simbólico";

c) o "complexo totalizante simbólico" deixou traços na obra de autores como Lévi-Strauss, Freud, Jung, embora estes (talvez à excepção do último), não lhe tenham entendido verdadeiramente o alcance.

\section{Oposições e sínteses: uma visão simbólica e totalizante}

A primeira oposição a considerar é a oposição Céu/Terra. O Céu desempenha o papel masculino, fecundando a Terra com a sua semente (chuva). Mas a chuva só cai depois de um movimento dialéctico operado no Céu. Na mitologia védica, de raiz indo-europeia, é Indra que arranca, através da batalha, a chuva ao dragão, o demónio avaro da seca, e fá-lo num movimento também triádico ${ }^{6}$. Este processo celeste vai desencadear a fecundação do solo e, por sua vez, um processo dialéctico na Terra. O funcionamento dá-se num duplo sentido: efectivo e metafórico. O que é que faz com um tal processo seja assimilado à oposição masculino/feminino, levando à "uterinização" da terra? O facto de todas as facetas da realidade partiharem um aspecto comum: só são inteligíveis em termos absolutos quando submetidos a esta leitura triádica da oposição e síntese. Desta forma, a oposição Céu/Terra torna-se o arquétipo de todas as oposições. Como tal, se o Céu é a morada dos deuses, a Terra torna-se a morada dos mortos. O facto de se colocar a morada dos mortos no mundo subterrâneo, de forma indiferenciada, colocando lado a lado justos e condenados, foi a principal razão para a assimilação original do inferno e do purgatório às profundezas subterrâneas. Esta tradição permaneceu inalterada até ao século XIV, altura em que Dante subverteu a tradição, colocando o Purgatório numa montanha junto ao Paraíso ${ }^{7}$. A oposição urânica-ctónica será, como foi dito, a matriz

6 Ver WIDENGREN, Geo - Fenomenologia de la Religion. Madrid: Ediciones Cristianidad, 1976, p. 55 e DUMÉZIL, Georges - L'idéologie tripartie des Indo-Européens. Bruxelles: Latomus, 1958, p. 46-47.

7 Teólogos como S. Tomás de Aquino ou S. Boaventura sugeriram que o Purgatório se localizava no centro da Terra, perto do Inferno, embora a relação e distância entre os dois permanecesse incerta, ver MORGAN, Alison - Dante and the Medieval Other World. Cambridge: University Press, 1990, p. 148. Sobre a aproximação topográfica do Purgatório 
de uma série de outras: masculino/feminino; Sol/Lua; Verão/Inverno; dia/noite; branco/negro; luz/trevas. Todos os pólos que se encontram do lado "luminoso" (céu, masculino, Sol, Verão, dia, branco, luz, etc.) partilham idêntica natureza, o mesmo se passando com os do lado das "trevas" (Terra, feminino, Lua, Inverno, noite, negro, trevas).

O gnosticismo, composto por grupos heterodoxos cristãos, florescentes nos primeiros séculos do cristianismo, explorou bastante estas oposições. $\mathrm{Na}$ mesma medida em que fazia funcionar a sua teologia, em função da luta entre a luz e as trevas, acabava por fazer dessa oposição o arquétipo de todos os restantes antagonismos. É interessante verificar que em algumas heresias medievais de raiz gnóstica, como os albigenses ou os Irmãos do Livre Espírito, se postulava que todas as acções cometidas com qualquer parte do corpo abaixo do umbigo não eram pecado ${ }^{8}$. No mundo grego antigo, influenciado, tal como os gnósticos, pelo dualismo indo-iraniano", os oráculos, nos quais se consultavam os espíritos das profundezas, tinham sempre uma pedra que se acreditava ser o ponto de ligação entre o mundo urânico e ctónico. O nome que a designava era omphalos, ou seja, umbigo ${ }^{10}$. Aquilo que está por detrás da proposição referida é apenas o prolongamento da cosmovisão dualista, assente na oposição entre o Céu e a Terra, aplicada ao corpo humano. A parte do corpo abaixo do umbigo partilha de uma natureza demoníaca, "escura", subterrânea, por oposição às partes superiores do corpo, identificadas com o Sol, Deus, a luz, o dia, etc. As zonas inferiores do corpo estavam, pela sua própria natureza, inclinadas necessariamente ao pecado. Uma constatação interessante é a de que uma formulação muito

ao Paraíso, operada por Dante, ver Le GOFF, Jacques - La naissance du Purgatoire. Paris: Gallimard, 1981, p. 17.

8 Para os albigenses ver RUNCIMAN, Steven - The Medieval Manichee. A Study of the Christian Dualist Heresy. Cambridge: University Press, 1984, p. 177; para os Irmãos do Livre Espírito ver McGINN, Bernard - The Harvest of Mysticism in Medieval Germany (1300-1500). New York: Herder \& Herder, 2005, p. 59.

9 A influência começou a dar-se por volta dos séculos VIII e VII a.C. através das colónias do Mar Negro, as quais entraram em contacto com os Citas, um povo de origem iraniana, cuja cosmovisão era essencialmente dualista e que transmitiu aos gregos o xamanismo trazido das estepes da Ásia Central, ver MEULI, Karl - Scythica. Hermes (1935) 121-176.

${ }^{10}$ Sobre a função do omphalos como ponto de intersecção entre os diferentes planos cósmicos ver KOROM, Frank J. - Of Navels and Mountains: A further inquiry in the History of an Idea. Asian Folklore Studies. 51 (1992) 103-125 e HARRISON, Jane E. - Delphika - a) The Erinyes b) The Omphalos. The Journal of Hellenic Studies. 19 (1899) 205-251. 
semelhante surge num autor místico condenado nos finais do século XVII, Miguel de Molinos, que defendia que quando a alma estava enlevada em contemplação, as acções cometidas com o corpo (parte inferior do ser humano enquanto totalidade) não eram pecado ${ }^{11}$. Aqui, a oposição urânica-ctónica é aplicada á dualidade corpo/alma e já não apenas ao corpo. Mas, como se disse, a metáfora é totalizante, aplica-se universalmente.

Um outro exemplo é o da organização social trifuncional, apresentada por Georges Dumézil como sendo exclusiva das sociedades indo-europeias ${ }^{12}$. No meu texto expus a forma como Dumézil deduziu a tripartição de funções na hierarquização social no mundo indo-europeu (no caso em questão tratava-se da sociedade romana) a partir da oposição Céu/Terra ${ }^{13}$. Defendi também que, de forma algo paradoxal, teria sido esta dedução, conjugada com a sua formação durkheimiana, que o impediu de ver a importância desempenhada pelo processo dialético, bem como de alargar essa perspectiva a toda a realidade.

Em suma, uma dada oposição de contrários funcionava como um microcosmos de todas as outras, sendo este aspecto que lhe conferia o seu carácter totalizante. Esta forma de inteligir o mundo possui dois grandes eixos arquetípicos: a já referida oposição Céu/Terra e o movimento dos astros, a alternância entre o Sol e a Lua, o Verão e o Inverno.

Como foi visto, esta cosmovisão implica um conjunto de analogias e associações, lua, mulher, noite, etc. (por um lado) e Sol, homem, dia, etc. (por outro). Uma das mais importantes que daqui resultam foi a já referida associação simultânea da Terra ao útero materno, por um lado, e ao mundo dos mortos, por outro. Uma tal associação implicou a homologia entre útero e mundo dos mortos. Nos oráculos da Grécia Antiga, a prática dos sonhos incubatórios implicava que o indivíduo que procurava contactar com o mundo subterrâneo deveria efectuar um conjunto de rituais purificatórios e

${ }^{11}$ Sobre a doutrina de Miguel de Molinos ver PELAYO, Menendez - Historia de los heterodoxos españoles, Madrid: Editorial Catolica, 1956, vol. II, p. 206-214 e TAVARES, Pedro Vilas Boas - Beatas, inquisidores e teólogos. Reacção portuguesa a Miguel de Molinos. Porto: CIUHE, 2005, p. 83-97.

${ }^{12}$ Diz Dumézil que "no mundo antigo (...) nenhum povo não indo-europeu explicitou, na prática ou idealmente uma tal estrutura", DUMÉZIL, Georges - L'idéologie tripartie des Indo-Européens. Bruxelles: Latomus, 1958, p. 11.

${ }^{13}$ Ver RIBEIRO, António - O Auto dos místicos..., cit., p. 419-424. 
envolver-se numa pele de carneiro ${ }^{14}$. $\mathrm{O}$ facto de esta prática se denominar incubação e implicar o envolvimento numa pele de animal, como se de uma membrana amniótica se tratasse, demonstra bem até que ponto a metáfora uterina está presente. A pele de carneiro desempenha a função de símbolo: para contactar os mortos é necessário renascer, fazer como eles, voltar ao útero materno. Para Richard Noll, num estudo sobre práticas xamânicas equivalentes, a função da pele animal vai um pouco além da dimensão simbólica, desempenhando um papel essencial na concentração e alheamento do mundo exterior ao praticante da incubação ${ }^{15}$.

Num estudo sobre um grupo friulano de contornos xamânicos, os benandanti, Carlo Ginzburg fez notar que o seu elemento distintivo era o facto de terem nascido envolvidos na membrana amniótica ${ }^{16}$. Em Portugal, aqueles que nasciam com uma ligação ao mundo dos mortos apresentavam algumas diferenças, mas o simbolismo é exactamente o mesmo: afirmavam ter um período anormalmente longo de gestação (vinte meses, cinco anos, etc.) ou ter a capacidade de falar ainda no ventre materno ${ }^{17}$. No primeiro caso trata-se de demonstrar um vínculo profundo e incomum ao ventre materno, tal como acontecia com os benandanti, que prolongavam a sua ligação trazendo consigo a coifa. No segundo caso, o indivíduo alega ter tido a capacidade de desempenhar funções cognitivas no útero, e de falar com a mãe, o que realça a sua função de mediador entre o mundo dos mortos e o dos vivos.

O ventre materno é, portanto, o símbolo do mundo dos mortos. É invocado através de uma representação da membrana amniótica. Uma pele de carneiro na Antiguidade. Através da utilização de uma capa, ou véu, no Portugal da Época Moderna. Era assim que a maior parte dos visionários

${ }^{14}$ FARNELL, Lewis Richard - Greek Hero cults and ideas of immortality. Oxford: Clarendon Press, 1921, p. 60.

${ }^{15}$ Para Noll, "o xamã neófito é treinado para aumentar a vividez da sua imagética visual mental através de técnicas psicológicas e fisiológicas. O objectivo é bloquear o ruído produzido pelos estímulos externos e debruçar-se em exclusivo sobre os processos de imagética internos". Trata-se, em suma, de "esquecer" o mundo exterior e voltar-se para o imaginário interior, ver NOLL, Richard - Mental Imagery cultivation as a Cultural Phenomenon: The Role of Visions in Shamanism. Current Anthropology. 26 (1985) 445.

${ }^{16}$ Ver GINZBURG, Carlo - Les Batailles Nocturnes. Sorcellerie et rituels agraires aux XVI et XVII siécles. Paris: Flammarion, 1984, p. 101-102 e GINZBURG, Carlo - História Noturna: decifrando o Sabá. São Paulo: Companhia das Letras, 1991, p. 150.

${ }^{17}$ Ver RIBEIRO, António - O Auto dos místicos..., cit., p. 376-377. 
e extáticos portugueses, tanto quanto os documentos o permitem aferir, entravam em contacto com o mundo dos mortos. Nos meios populares era frequente a utilização de uma manta, ou, mais raramente, cobrindo-se de palha ou de terra ${ }^{18}$.

A Terra feminiliza-se. Torna-se símbolo. A capa ou véu uterinizam-se. Tornam-se igualmente símbolos. A questão que se coloca é a de saber em que medida esse simbolismo é interiorizado como mera metáfora ou é percebido como tendo um poder efectivo.

Como foi mencionado, Richard Noll colocou em evidência o facto de o uso de peles na prática incubatória não ser apenas simbólica, mas ter uma função psico-fisiológica de alheamento do mundo exterior. No fundo, uma dimensão semelhante à que Francisco de Osuna referia para a prática do recogimiento: esquecer as imagens e "recolher o que estava disperso". A Terra, por seu turno, tem também uma função que vai para além dos aspectos simbólicos. Ela é o símbolo da terra dos mortos, mas recolhe efectivamente os mortos no seu seio. Neste sistema simbólico, como foi visto atrás, a dialéctica, a superação de contradições e a ideia de morte e renascimento têm uma função fundamental. Olhada sob esta perspectiva, a Terra é um exemplo perfeito. Dela nasce a vida e para ela se retorna no momento da morte. Surpreendentemente, da Terra nascem, como demonstrei no meu texto, anúncios de fortuna e de morte, pontuados pelo incessante devir do tear da moira $^{19}$. Daí o carácter ambíguo que a figura da mãe apresenta, aspecto que será retomado mais á frente, quando se abordar a questão da psicanálise.

O símbolo tem, assim, um duplo aspecto: metafórico e efectivo. A ideia poderá ser utilmente aprofundada recorrendo à observação de um conjunto de manifestações que designei como "parto místico"20. Normalmente trata-se de uma mulher que afirma estar prenhe de um ser extraordinário, uma figura de contornos fantásticos, destinada a salvar ou reformar o mundo. Em poucas palavras, um messias. A forma como esta "fecundação" se efectua dá uma

\footnotetext{
${ }^{18}$ Ver RIBEIRO, António - O Auto dos místicos ..., cit., p. 364.

${ }^{19}$ Ver RIBEIRO, António - O Auto dos místicos..., cit., p. 347-350.

${ }^{20}$ Ver RIBEIRO, António - O Auto dos místicos..., cit., p. 396-400.
} 
perspectiva interessante da função mediadora do símbolo entre a metáfora e a acção efectiva.

Antónia Rodrigues (1675), moradora em Abrantes, era frequentemente visitada por uma mulher, uma moira, que "metendosse outra dentro nella confitente, e quando entrava nella sentia a modo de huma cobra que the fazia inchar o estomago com tal aperto e ancia que pegando nella confitente quatro ou sinco pessoas a não podião sigurar, e neste tempo dezejava ella confitente sair se de caza, e ir se afogar no Tejo"21. Num outro caso, Maria da Nazaré (1714), moradora na Pederneira, junto à Nazaré, afirmou a dada altura "que tivera hua cobra enroscada em si e que estando em extazi ficou aliviada"22. É óbvio que do que aqui se trata é de casos de possessão por um espírito, frequentemente reportados nos arquivos inquisitoriais, nos quais a cobra funciona como símbolo.

No seu clássico Tratado de História das Religiões, Mircea Eliade refere a dada altura que "na Alemanha, em França, em Portugal e em outras regiões, as mulheres temem que uma serpente lhes entre na boca durante o sono e as fecunde, em especial no período menstrual"23. Estas palavras podem ser corroboradas por factos. Isabel de Jesus, uma visionária denunciada à Inquisição portuguesa, em 1562, relatou à mulher que a denunciou "que emprenhara de hua cobra e andara quatorze meses prenhe"24. Foi já visto que uma gestação anormalmente longa era expressão de uma ligação ao mundo uterino, o mundo dos mortos, algo que atribuía dons excepcionais ao indvíduo que deveria nascer. Articulando este facto com a ideia de que a entrada da cobra no corpo da mulher implica uma forma de possessão, forçoso será conlcluir que a mesma possessão, elemento espiritual e psíquico, podia determinar uma acção efectiva, física, uma gravidez.

Porquê a serpente? Como procurei demonstrar a serpente é a parte luminosa do mundo ctónico, do mundo dos $\operatorname{mortos}^{25}$. A razão é facilmente explicável: ela vive debaixo da terra, na companhia dos mortos, durante os

${ }^{21}$ Cf. Arquivo Nacional da Torre do Tombo (doravante ANTT) - Inquisição de Lisboa, processo ${ }^{\circ} 9577$, fl. 49.

${ }^{22}$ Cf. ANTT - Inquisição de Lisboa, Livro 275, fl. 194.

${ }^{23}$ ELIADE, Mircea - Tratado de História das Religiões. Porto: Edições Asa, 1994, p. 218 (a edição original francesa é de 1953).

${ }^{24}$ Cf. ANTT - Inquisição de Lisboa, Livro 193, fl. 206.

${ }^{25}$ Ver RIBEIRO, António - O Auto dos místicos..., cit., p. 352 e ss. 
seis meses "escuros" de Outono e Inverno, mas acompanha o ritmo do Sol, regressando à superfície durante os seis meses de Primavera e Verão. Importa recordar que os dois eixos nos quais se estrutura toda esta mitologia são, por um lado, a oposição Céu/Terra, por outro, a alternância dos astros, do Sol e da Lua. Enquanto símbolo do mundo dos mortos a serpente encarna a dupla vertente metafórico-efectiva, ela vive "efectivamente" debaixo da terra. No entanto, ao acompanhar os ritmos do Sol, ela torna-se o seu símbolo. É um exemplo acabado desta intrincada teia de contradições e antíteses, é a luz do Sol no mundo das trevas. Eliade refere ainda alguns indivíduos da Antiguidade, como Alexandre Magno ou Augusto, de quem se dizia que tinham sido concebidos através da cópula da mãe com uma serpente.

Na psicanálise, como se verá, este conjunto de mitos foi encarado como uma manifestação de desejos recalcados, conclusão atribuída, em grande medida, à forma fálica da serpente. Em face do que até aqui foi exposto será legítimo questionar se a cópula não será mais metafórica do que efectiva, ou se não será uma mediação entre as duas. Tanto mais que a fecundação pela boca, recorrente nestes casos de "parto místico", ocorria com outros animais simbólicos, cuja forma não é, manifestamente, fálica, (uma pomba, por exemplo), ou podia ocorrer ainda através de um feixe de luz (o Espírito Santo $)^{26}$.

Como foi dito, a serpente simboliza o Sol. E ao Sol, bem como à luz, eram atribuídas qualidades progenitoras. Como bem notou Eliade, no contexto eurasiático o semen virile era considerado como uma epifania solar $^{27}$. Atente-se num caso ocorrido em Lisboa, no ano de 1721, de uma mulher "natural de Arcos de Vadeves, e que ao prezente asiste em a Guarda da Raynha Nossa Senhora", a qual afirmou que fora "gerada no Ceo e creada na terra porquanto a sua may a concebera sem ser por obra de varão e so por vertude de hua reliquia que lhe viera do Ceo a terra no olho do Sol, e que andara hum anno em o ventre de sua may"28. Num outro caso, ocorrido em 1754, uma mulher, de nome Madalena, declarou ter sido questionada pelo rei (presumivelmente D. José I), o qual pretendia saber “do conhecimento

\footnotetext{
${ }^{26}$ Ver RIBEIRO, António - O Auto dos místicos..., cit., p 397-398.

${ }^{27}$ Ver ELIADE, Mircea - Spirit, Light, and Seed. History of Religions. 11 (1971) 1-30.

${ }^{28}$ Cf. ANTT - Inquisição de Lisboa, Livro 282, fl. 603-604.
} 
que se diz della ter do Sol", ao que ela respondeu que "o Sol tem varios Rayos de diversas cores; e que ou certo rayo do Sol ou certa estrela ou rayo de estrela significa hum parto secco que a Virgem Nossa Senhora tivera"29. Ainda noutro episódio, em 1691, um eremita de Mogadouro, o "irmão António", terá afirmado que "lhe he comunicado como se governa o mundo pelos Astros, e que somos concebidos nos ventres de nossas maes por feitiçaria, e chama feitiçaria a influencia dos Astros" ${ }^{30}$. Revela-se assim, em suma, um intrincado complexo simbólico, com a serpente a assumir as qualidades progenitoras atribuídas ao Sol, o astro que ela simboliza. A serpente simboliza também os espíritos dos mortos e, assim, operando uma síntese a partir do carácter ambíguo da serpente, dá-se a gestação de uma criança excepcional, gerada pelas propriedades fecundadoras do Sol, em íntima ligação com o mundo dos mortos.

Estas propriedades resultam do facto de, na cosmovisão dualista de funcionamento triádico, referida no início deste texto, o Sol equivaler ao Céu, e este, por sua vez, equivaler ao princípio masculino, ao primeiro termo do processo fecundante triádico. Mas a ligação entre a serpente, o Sol e o simbolismo ginecológico da Terra pode ser ainda mais aprofundada, se nos debruçarmos sobre as lendas de mouras encantadas, existentes no folclore português. Estas eram, por norma, figuras híbridas, meio mulher, meio serpente, que apareciam no dia do solstício de Verão exibindo um tesouro. O facto de surgirem nesse dia em particular, o dia que tem mais horas de Sol no ano, confirma o que foi dito acima. Por outro lado, a hibridez entre o mundo humano e animal reflecte o pensamento impregnado de contradições, opostos e sínteses que subjaz a todo este complexo simbólico. Finalmente, a questão do ouro deriva directamente da sexualização e "uterinização" da Terra. Neste complexo simbólico arcaico, os metais são vistos sob uma perspectiva embriológica, ou seja, acreditava-se que os metais obedeciam a uma maturação, como se de um feto se tratasse. O ouro, pensava-se, era formado por fecundação do Sol, desenvolvendo-se a partir do bronze,

\footnotetext{
${ }^{29}$ Cf. ANTT - Inquisição de Lisboa, livro 305, fl. 283.

${ }^{30}$ Cf. ANTT - Inquisição de Coimbra, Livro 315, fl. 127 e seguintes.
} 
passando por uma prolongada gestação no interior da Terra ${ }^{31}$. Novamente o cosmos como arquétipo do homem.

Como tentei demonstrar no Auto dos místicos, a contrapartida "escura" da serpente é o lobo $^{32}$. Se a serpente se identifica com o Sol, por uma analogia facilmente compreensível, o mesmo se passa com o lobo em relação à Lua.

Os arquivos da Inquisição portuguesa estão repletos de vestígios de comportamentos que apontam no sentido da licantropia. Estes, tal como a prática da incubação, simbolizam a ligação ao mundo dos mortos. Em certo sentido, a incubação e a licantropia são duas faces da mesma moeda. Com uma diferença, porém. A incubação resulta de um acto voluntário do indivíduo que pretende ser iniciado no contacto com o mundo dos mortos. No caso da licantropia, são os mortos que efectuam um "chamamento", os mortos fazem do iniciado "um dos seus". Chamamento que aparece noutros contextos, ligado, tal como Portugal, ao xamanismo ${ }^{33}$.

Como tive a oportunidade de demonstrar, esse acontecimento dava-se, no caso português, aos sete anos de idade. Era uma altura em que o neófito sentia uma brusca mudança de comportamento ${ }^{34}$. Foi ainda possível apurar que esses elementos xamânicos, nos quais se inclui, obviamente, o chamamento, foram assimilados pela hagiografia oficial da Igreja. Dessas mudanças bruscas de comportamento, a mais desconcertante tem a ver com a fuga nocturna do iniciado para zonas ermas, montes e florestas. No que diz respeito aos arquivos inquisitoriais, numa busca não exaustiva, os casos surgem em abundância. Luísa João (1753), de Coimbrão de Cima, perto de Leiria, fugia de noite para o mato, onde dava "gritos e voziarias espantosas", que as testemunhas definiam como "rosnaduras"

${ }^{31}$ ELIADE, Mircea - Forgerons et alchimistes. Paris: Flammarion, 1977, p. 41.

${ }^{32}$ Ver RIBEIRO, António - O Auto dos místicos..., cit., p. 382.

${ }^{33}$ Ver PÓCS, Éva - Possession phenomena, possession-systems. Some East-Central european examples in KLANICZAY, Gabor; PÓCS, Éva (ed.) - Communicating with the Spirits. Budapest; New York: Central European University Press, 2005, p. 95. No contexto siberiano este chamamento não era feito por um morto qualquer, ou por um demónio, mas era efectuado pelo espírito de um antepassado, ver ELIADE, Mircea - Le chamanisme et les techniques archaiques de l'extase. Paris: Payot, 1978, p. 76.

${ }^{34}$ Ver RIBEIRO, António- O Auto dos místicos..., cit., p. 377-382.

${ }^{35}$ Cf. ANTT - Inquisição de Lisboa, processo no ${ }^{\circ}$ 5183, fl. 9. 
Uma testemunha afirmou que "por duas vezes tem ouvido fora de horas huns eccos horrendos mas que não sabe que he e dizem algumas pessoas a tem encontrado fora de caza depois dos galos cantarem e que tãobem lhe tem ouvido dizer que ella tem aquellas inquietaçoins porque seo marido a vem

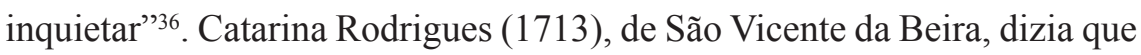
o demónio "lhe aparecia em figura de lobo, e que de noite a tirava da sua cama, e a levava a serra, e despindoa a deichava ahi" ${ }^{37}$. Sebastiana de Jesus (1710), utilizava um cordão de S. Francisco como protecção "o qual a havia de livrar que a não matase hum demonio que de noite a vinha buscar"38. À já referida Maria da Nazaré (1714), moradora na Pederneira, acontecia que em "algumas ocaziens de luas foge de caza de sua may, e se vay pellos mattos, quer seja de noute, quer seja de dia, e dá grande cuydado a sua may e a seus irmãos pera a hirem buscar" 39 . Refiram-se ainda os casos de Águeda, uma "molher do campo, asistente nas partes de cima do Douro", frequentadora do Convento da Madre de Deus de Monchique, no Porto, a qual saía de noite para "huma cova que estava em hum monte oculta cheia de ortigas sobre as quais ella despida nua se lansava" ${ }^{40}$, ou de Soror Maria Eugénia da Trindade (1745), moradora num convento em Évora, a qual "queria pregar de missão que assim lho ordenava hum menino que tinha dentro em si que era Deos" e que, segundo a denúncia de Soror Catarina Micaela, "inquieta as comunidades e rindo dá uivos como cão"41.

Há três elementos que definem estes comportamentos como licantrópicos: a) a fuga para locais ermos; b) a nudez ritual, que aparece duas vezes ${ }^{42}$; c) um comportamento similar ao de cães ou lobos. De referir ainda o aspecto do "chamamento", que aparece referido expressamente três vezes, e a significativa referência às "ocasiões de luas", filiando este comportamento na

${ }^{36}$ Cf. idem, fl. 19.

${ }^{37}$ Cf. ANTT - Inquisição de Lisboa, Livro 272, fl. 291.

${ }^{38}$ Cf. ANTT - Inquisição de Lisboa, processo 11488, fls. não numerados.

${ }^{39}$ Cf. ANTT - Inquisição de Lisboa, Livro 275, fl. 236.

${ }^{40}$ Cf. ANTT - Inquisição de Coimbra, Livro 362, fl. 93.

${ }^{41}$ Cf. ANTT - Inquisição de Évora, Livro 273, fl. 204.

${ }^{42}$ Compare-se com o caso dos Lupercus, os homens que, durante o festival romano de Inverno das Lupercalia, corriam "sem vestimentas humanas, com ou sem vestimentas animais" pelo antigo cemitério de Roma, imitando o comportamento dos lobos, ver DUMÉZIL, Georges - Le problème des Centaures. Paris: Geuthner, 1929, p. 213. 
mitologia solar e no complexo simbólico que tem vindo a ser estudado ao longo deste artigo. Não irei retomar a longa genealogia da licantropia. Basta, para o que aqui interessa, relembrar que, segundo o folclore vigente em vários pontos da Europa, os lobisomens vagueavam pela terra durante o período que vai do Natal até à Páscoa, ou seja, de uma forma geral, entre o solstício de Inverno e o equinócio da Primavera ${ }^{43}$. Em termos ainda mais gerais: o Inverno. Marcelo de Side, autor que vivieu no século II d.C. comentou que a incidência de licantropia, o hábito de sair de noite para os ermos e cemitérios, imitando cães e lobos, era ainda mais notada em Fevereiro, a meio do Inverno ${ }^{44}$.

O lobo, o Inverno, a noite, a Lua. À excepção do Inverno, todos os outros elementos aparecem referidos nos casos mencionados acima. Há a juntar ainda o elemento terra, presente na cova onde Águeda se lançava nua. As covas eram os locais onde se encontravam os oráculos com as suas pedras umbilicais, eram portas para o mundo uterino (delph, o mais famoso dos oráculos, significa precisamente útero). Todos estes elementos são "sombrios" e homólogos da mitologia solar.

O caso não era exclusivo de Portugal. Nos alumbrados espanhóis registam-se referências semelhantes ${ }^{45}$. Certamente que não será sequer um exclusivo ibérico. Há ainda um elemento que, apesar de algo especulativo, se adequa de forma perfeita a todo este complexo simbólico. Se a contrapartida da serpente é o lobo, e o homólogo da serpente, no que diz respeito ao mundo dos metais, é o ouro, qual seria o correspondente ao lobo? É especulativo, repito, mas perfeitamente lógico. Segundo um mito extremamente difundido, os lobisomens só morrem com balas de prata. O lobo é, tal como a serpente, um símbolo do mundo dos mortos. É a contrapartida escura de um mundo já

${ }^{43}$ SENN, Harry - Romanian Werewolves: Seasons, Ritual, Cycles. Folklore. 93 (1982) 206-215.

${ }^{44}$ Ver MICHELS, Agnes Kirsop - The Topography and Interpretation of the Lupercalia. Transactions and Proceedings of the American Philological Association. 84 (1953) 53.

${ }^{45}$ Alguns alumbrados da Estremadura espanhola afirmaram que "les daba um espíritu violento y las hacia caminar a la posta". Num caso, referido por Álvaro Huerga, "una doncela "alumbrada" se marchó impelida por el epíritu diabolico, por veredeas y montes sin poderlo resistir", ver HUERGA, Alvaro - Los Alumbrados de Extremadura (1570-1582). Madrid: Fundacion Universitaria Española, 1986, p. 132. 
de si escuro. É o paroxismo da escuridão. Assim, o lobo é o correspondente à prata no universo dos metais.

Para finalizar esta exposição sobre o "complexo totalizante simbólico" importa referir ainda dois símbolos que são, ao contrário dos que foram referidos até aqui, sintéticos. A noite, a Lua, o Céu, etc., são elementos "antitéticos", ou seja, pertencem a um dos pólos de opostos. Contudo, como referi acima, a perspectiva dualista adquire a sua dimensão absoluta através da introdução de um terceiro termo, que faz a síntese entre os outros dois. Os símbolos a que me refiro são a árvore e o tear.

$\mathrm{O}$ tema da árvore foi já exposto no Auto dos Místicos. A sua dimensão de símbolo sintético, de mediador entre o alto e o baixo, resulta do facto de ter as raízes mergulhadas na Terra e de projectar os seus ramos para o Céu ${ }^{46}$. A árvore torna-se assim um axis mundi, um eixo no qual se estruturam os diferentes níveis cósmicos ${ }^{47}$. A sua presença é recorrente em várias aparições registadas na Inquisição.

Muito mais discreta é a presença do tear enquanto símbolo de síntese. A tríade ctónica, por excelência, é a das moirai, divindades do mundo grego antigo, cuja existência, mantendo precisamente a designação grega (moira), é facilmente detectável no folclore português. As moirai são três: Kloto (a fiandeira), Lachesis (a distribuidora) e Atropos (a fatalista). A distribuidora e a fatalista, anunciadora da morte, estão amplamente documentadas nos arquivos inquisitoriais. Mas entre estes dois pólos opostos, entre a distribuidora da fortuna e a anunciadora da morte, há um terceiro, a moira fiandeira, a que faz girar o seu tear de um ponto para o outro, incessantemente. A moira fiandeira, tal como o som do seu tear, que alguns julgavam ouvir

${ }^{46}$ Ver o capítulo "As entranhas da Terra e os quatro sonhos do escravo" in RIBEIRO, António - O Auto dos místicos..., cit., p. 309-327.

${ }^{47}$ A análise de Simo Parpola acerca do tema da árvore, tendo como exemplo o mundo semita (assírio, hebraico), mas sem esquecer influências e relações com o mundo indo-europeu (grego), acaba por confirmar a persepctiva que tenho vindo a expor. Vejam-se as seguintes passagens: "tal como a árvore assíria, a árvore sefirótica tem uma dupla função. Por um lado, é a figura do macrocosmos, (...) [por outro] ela representa a harmonia cósmica do universo suportada pelo Sefirot sob a influência coerciva do sistema polar de opostos", ver PARPOLA, Simo - The Assyrian Tree of Life: tracing the origins of jewish monotheism and greek philosophy. Journal of Near Eastern Studies. 52 (1993) 171-172. Sefirot é um termo hebraico, ligado à cabala, que significa literalmente "números" ou "contagens". Tem um sentido esotérico. 
vindo do chão, faz parte do folclore português ${ }^{48}$. Já a sua função mediadora, de devir, a sua função simbólica, tem sido ignorada.

Mircea Eliade colocou em evidência a importância que termos como "rodar", "fuso" ou "roca" tiveram, em algumas línguas indo-europeias, para designar a palavra destino ${ }^{49}$. O destino é feito de múltiplas situações contraditórias. Veja-se, a propósito, o comportamento de um heresiarca de Mondim de Basto, João Pinto, numa sessão de exorcismo, em 1759. No momento em que uma sua acólita caía por terra, possuída por um espírito, João Pinto disse: "fia na tua roca, que eu não bulo contigo" dirigir-se ao espírito, que viera do mundo dos mortos. O simbolismo do tear, estando ligado às regiões subterrâneas, acabaria por se conotar com o demónio. Isso é evidente em dois casos surgidos na Inquisição, um de Bragança (1712) e outro de Lisboa (1663). O primeiro é um extenso relato das visões de João Rodrigues do Canto, um homem do campo, vexado pelos demónios, a quem, a dada altura, foi "mostrada huma caza com hum enredozo tear toda coberta de varios fios a maneira de laços e dela sahia hua procissão de demonios vestidos de diversas cores"51. No caso de Brites da Mota, servente do convento de Santa Mónica, de Lisboa, foi uma visão, estando na cama a padecer uma enfermidade, "olhando casualmente para o tecto da casa, vio com os olhos corporaes hum tear de ferro, e nelle hum rostro negro e disforme e humas mãos tecendo no ditto tear" ${ }^{2}$. À semelhança do que aconteceu com a serpente, com o lobo ou com o véu, também o estatuto simbólico do tear, enquanto símbolo da dialética e do devir, foi desaparecendo, vendo a sua carga simbólica substituída pela sua presença efectiva. Neste caso nem sequer se verifica, como naquelas situações, uma identificação entre símbolo e conceito simbolizado. Em relação ao tear

${ }^{48}$ Ver VASCONCELOS, José Leite - Opúsculos. Lisboa: Imprensa Nacional, 1938, p. 501. As referências ao som do tear aparecem já no mundo grego, ver COULTER, Cornelia C. - The Hapy Otherworld and Fairy Mistress Themes in the Odissey. Transactions and Proceedings of the American Philological Association. 56 (1925) 44-45.

${ }^{49}$ ELIADE, Mircea - Tratado..., cit., p. 236.

${ }^{50}$ RIBEIRO, António - Um buraco no Inferno: João Pinto, o lavrador heresiarca e a Inquisição. Viseu: Palimage, 2006, p. 152-153.

${ }^{51}$ ANTT - Inquisição de Coimbra, Livro 332.

${ }^{52}$ ANTT - Inquisição de Lisboa, processo n ${ }^{\text {o } 3477, ~ f l . ~ 4-5 . ~}$ 
há uma "demonização" do objecto, uma conotação ao mundo dos mortos, o que não corresponde ao seu conceito inicial.

\section{O complexo, a antropologia e a psicanálise}

Após a exposição sucinta deste "complexo totalizante simbólico", que sendo "totalizante" é composto por um número infinito de outros símbolos não abordados aqui, importa tentar compreender de que forma é que esta cosmovisão colectiva se manifestou objectivamente, nomeadamente em vertentes como a religião e o mito. Para tal, seleccionei um conjunto de textos de Lévi-Strauss, Freud e Jung, ou de autores que gravitam na órbita destes, no sentido de os analisar à luz do que atrás foi exposto.

Oscilar entre Lévi-Strauss, por um lado, e Freud e Jung, por outro, é polarizar a análise entre as disciplinas que estes autores representam, a antropologia e a psicanálise. Para articular o "complexo totalizante simbólico" com estas duas áreas é adequado começar por dois textos publicados por Lévi-Strauss na sua Anthropologie structurale. No primeiro, L'efficacité symbolique, é abordado um assunto central ao longo deste estudo: a eficácia e a acção efectiva do símbolo ${ }^{53}$. Ali, o objecto de análise é uma cerimónia xamânica efectuada sobre uma parturiente. $\mathrm{O}$ cenário é o Panamá, e desenrola-se no seio dos cuna, uma tribo indígena. $\mathrm{O}$ autor sugere que a acção do xamã é, em grande medida, análoga à do psicanalista. O tratamento que é efectuado não implica qualquer contacto físico. O xamã cria um mundo simbólico para representar o útero dorido da parturiente. E, surpreendentemente, o símbolo que é criado é o do mundo infernal, povoado por demónios (as dores). Este é o primeiro aspecto curioso. O símbolo é o mesmo que aparece no complexo xamânico eurasiático, o qual, como tentei demonstrar no Auto dos místicos, esteve na origem remota da formação da cosmovisão religiosa portuguesa e europeia. Mas regresse-se à cerimónia cuna. Segundo o xamã, a mulher sofre porque perdeu o seu duplo, (que se poderia traduzir por alma), aprisionado pelos espíritos malignos nas profundezas infernais. $\mathrm{O}$ xamã enceta então uma viagem espiritual ao

${ }^{53}$ LÉVI-STRAUSS, Claude - Anthropologie structurale. Paris: Plon, 1974, p. 213-234. 
mundo demoníaco, simbolizado, como já foi dito, pelo útero. Segundo Lévi-Strauss, é o canto, a ladainha que é recitada de forma monocórdica durante a cerimónia, que começa a conferir autenticidade à metáfora, principiando, de alguma forma, a fundir o símbolo com o conceito simbolizado. O xamã inicia a sua viagem de uma forma simbólica mas, a pouco e pouco, segundo as palavras do autor "a penetração da vagina, por mais mítica que ela seja, é proposta à doente em termos concretos e conhecidos" ${ }^{24}$. Um pouco mais á frente o autor reforça a ideia: "trata-se de uma relação do símbolo com a coisa simbolizada, ou, para utilizar o vocabulário dos linguistas, do significado com o significante. $\mathrm{O}$ xamã fornece à sua doente uma linguagem na qual se podem exprimir estados informulados e informuláveis. É a passagem a esta expressão verbal (...) que provoca o desbloqueamento do processo fisiológico" "55. Para o antropólogo francês este processo é análogo à psicanálise, uma vez que se propõe "transmitir à consciência os conflitos e resistências que estavam, até então, inconscientes, seja em razão do seu recalcamento por outras forças psicológicas, seja - como no caso do parto - por causa da sua própria natureza, que não é psíquica mas orgânica, ou mesmo simplesmente mecânica" ${ }^{56}$. Contudo, há diferenças - continuando a seguir Lévi-Strauss - e uma delas é que na psicanálise o mito que se faz reviver é individual, enquanto que o mito que o xamã faz reviver à sua paciente é um "mito social" que o verdadeiro alcance do simbolismo da cerimónia descrita escapou, em grande medida ao antropólogo. O simbolismo terra-útero é mais do que um "mito social", é um fragmento de uma cosmovisão totalizante. É um dos inúmeros signos utilizados pela mente humana para pensar o absoluto.

${ }^{54}$ LÉVI-STRAUSS, Claude - Anthropologie..., cit., p. 222.

${ }^{55}$ LÉVI-STRAUSS, Claude - Anthropologie..., cit., p. 226.

${ }^{56}$ Esta semelhança entre piscanálise e xamanismo, nos mesmos termos em que a questão é colocada por Lévi-Strauss, aparece bem desenvolvida em DOW, James - Universal Aspects of Symbolic Healing: a Theoretical Synthesis. American Anthropologist. 88 (1986) 56-69. Segundo Dow, "a cura é frequentemente baseada na restruturação de uma desordem modelada num mundo mítico". Mais à frente afirma que "no processo de cura o curandeiro particulariza uma parte do mundo mítico geral para o paciente e interpreta o problema do paciente em termos de uma desordem no segmento particularizado", ver p. 59-60.

${ }^{57}$ LÉVI-STRAUSS, Claude - Anthropologie..., cit., p. 228. 
É este "complexo totalizante simbólico" que permite ainda estabelecer uma relação subtil com o texto que, na Anthropologie structurale, sucede imediatamente ao da cerimónia xamânica. Falo de La structure des mythes ${ }^{58}$.

Aqui, o antropólogo ataca a perspectiva de Jung acerca dos mitos, a qual vê sempre um significado por detrás de cada padrão mitológico. Isto é, para Lévi-Strauss, "comparável com o erro sustentado desde há muito de que um determinado som possui uma certa afinidade com um significado" 59 . $\mathrm{O}$ autor tenta, portanto, uma abordagem ao mito pela via metodológica da linguística. Assim, como os linguistas desconstroem as frases e palavras, dividindo-as em fonemas, Lévi-Strauss estudou o mito de Édipo dividindo-o em "mitemas". Não irei abordar em detalhe a análise, bastante complexa aliás, feita pelo autor. Basta registar a ideia de que os padrões mitológicos (por exemplo o incesto, um tema recorrente na mitologia grega e não só) não têm um significado, e que os mitos devem ser desconstruídos e dissecados para se chegar à sua estrutura, a qual deve ser, defende o estruturalista, universal.

Através da sua interpretação, contudo, chega a algumas conclusões em sintonia com a perspectiva do "complexo totalizante simbólico". Nomeadamente a ideia de que a base estrutural dos mitos tem uma natureza dialéctica assente na luta de opostos. O problema fundamental do mito era "como é que o um pode nascer de dois" $"$. Édipo mata o pai. Ultrapassa-o. É uma síntese de dois opostos que se juntaram. Nisso, o "complexo totalizante simbólico" coincide com a tese de Lévi-Strauss, o qual vê em Édipo o terceiro elemento de uma tríade. Mas, como terceiro elemento, Édipo representa o devir, o movimento, o tempo. E o tempo mata. Mas atente-se no papel do pólo oposto ao pai, Jocasta, a mãe de Édipo, e relembre-se o estatuto ambíguo de mãe e de receptora dos mortos, que é desempenhado pela Terra, explicitado no início deste estudo. Édipo nasceu de Jocasta e a ela regressou, e o seu regresso gerou a sua morte. Esta ideia ganha ainda

${ }^{58}$ LÉVI-STRAUSS, Claude - Anthropologie..., cit., p. 235-275. A edição original do texto, e que será a utilizada aqui, é de 1955, ver LÉVI-STRAUSS, Claude - The Structural Study of Myth. The Journal of American Folklore. 68 (1955) 428-444.

${ }^{59}$ LÉVI-STRAUSS, Claude - The Structural Study..., cit., p. 429.

${ }^{60}$ LÉVI-STRAUSS, Claude - The Structural Study..., cit., p. 435. 
mais força num pormenor que o antropólogo francês reconheceu. A íntima ligação entre Édipo e o mundo subterrâno, patente no facto de Édipo ser manco. Diz o autor que "na mitologia, um aspecto universal dos homens que nascem da terra é que, no momento em que emergem das profundezas, eles não conseguem andar, ou fazem-no de forma desastrada" ${ }^{\text {"1 }}$. O padrão mítico do incesto tem, ao contrário do que prentendia Lévi-Strauss ao criticar Jung, um significado: é um símbolo do devir inexorável, do princípio xamânico de morte e renovação. É o equivalente, num plano diferente da realidade, ao tear da moira.

O mito de Édipo e a ideia de incesto foi igualmente alvo da atenção de Sigmund Freud. A sua perspectiva era a de que este mito constituía a expressão de um conjunto de desejos e impulsos irracionais e antisociais ${ }^{62}$. A atracção sexual do filho pela mãe e a revolta contra o pai, defende Freud, são elementos que surgem em estádios precoces da existência masculina e que vão sendo sublimados (substituídos) com a idade. O mito de Édipo é, assim, a tradução literal, não mediada pelo símbolo, do instinto humano básico, tal como o entendia o pai da psicanálise. Neste caso, curiosamente, o mito nem sequer surge coberto pelo véu da censura que Freud afirmava existir em todos os sonhos humanos, uma censura que, segundo defendia, se destinava a mascarar os instintos que a consciência se recusava a reconhecer existirem em cada um de nós. Um dos mais dedicados discípulos de Freud, Karl Abraham, nota esta contradição na interpretação do seu mestre sem, contudo, colocar em causa a sua validade: "os sonhos de morte do pai e de trato sexual com a mãe (...) constituem uma excepção notável, na medida em que um desejo que nos assustaria em estado de vigília, é apresentado sem qualquer disfarce simbólico"63. Na verdade, em face do exposto, o mito de Édipo constitui um disfarce simbólico, não de instintos irracionais ou antisociais, mas da inevitabilidade do destino humano, quando confrontado com a marcha irreversível do tempo. De resto, a mitologia grega apresenta uma série de outros elementos que o reforçam. Veja-se o caso da teogonia

${ }^{61}$ LÉVI-STRAUSS, Claude - The Structural Study..., cit., p. 434.

${ }^{62}$ FROMM, Erich - The forgotten language. An introduction to the understanding of dreams, fairy tales and myths. New York: Grove Press, 1951, p. 196 e ABRAHAM, Karl Psychanalyse et culture. Paris: Payot, 1969, p. 13.

${ }_{63}$ ABRAHAM, Karl - Psychanalyse..., cit., p. 14. 
de Zeus, ao qual o pai, Cronos, tenta devorar quando ele nasce. Zeus é colocado numa gruta para ficar a salvo da acção do seu pai. Cronos é o tempo, o devir, a multiplicidade, a luta de opostos. A colocação de Zeus na gruta constitui um regresso, um superação de opostos, um momento unitivo. Zeus é colocado num plano superior.

A ênfase colocada por Freud na questão sexual impede-o de ver a natureza simbólica e dialéctica do mito. Isso é, talvez, ainda mais nítido num outro texto do vienense. Em The theme of the three caskets, Freud debruça-se sobre um momento do Mercador de Veneza, de Shakespeare, em que três personagens, o príncipe de Marrocos, o príncipe de Aragão e um terceiro, Bassanio, devem optar por um de três cofres, cada um dos quais é feito de um material diferente: ouro, prata e chumbo ${ }^{64}$. Bassanio escolhe o terceiro, desvalorizando o ouro como enganador e a prata como vulgar. $\mathrm{O}$ chumbo parece ser, aos olhos de Bassanio, o mais verdadeiro. O tema pertence, como bem viu Freud, a uma compilação de lendas medievais, a Gesta Romanorum. Através de um estudo de Eduard Stucken, Freud reconheceu que a identidade dos três personagens tinha uma correspondência astral: o príncipe de Marrocos era o Sol, o de Aragão era a Lua e Bassanio era "o filho da estrela". Mais uma vez se nos depara o "complexo totalizante simbólico". Freud afirma, aparentemente surpreendido: "o nosso pequeno problema levou-nos a um mito astral!” Mas, para o vienense, os mitos são projecções astrais de problemas bem humanos. O que verdadeiramente está em causa neste tema shakespereano é, afirma, a escolha entre três mulheres. O cofre é o disfarce simbólico sob o qual o "censor" do inconsciente esconde a figura da mulher. O pai da psicanálise socorre-se de outros exemplos para ilustrar esta ideia. No Rei Lear, a escolha entre as três filhas esconde a opção de um homem velho a escolher mulheres mais novas, das quais a terceira é a mais excelente, a mais nova, a mais bela.

Mas Freud reconhece um facto: "deve surpreender-nos que esta excelente terceira mulher tem, em vários aspectos, certas qualidades particulares para além da sua beleza. São qualidades que parecem tender para uma qualquer

${ }^{64}$ FREUD, Sigmund - The theme of the three caskets in The standard edition of the complete psychological works of Sigmund Freud. London: Hogarth Press, 1973, vol. XII (1911-1913), p. 291-301. 
espécie de unidade”. Até aqui, a análise parece convergir com a que é proposta pelo "complexo totalizante simbólico". Mas, imediatamente a seguir, Freud ignora completamente esta ideia de unidade, para se debruçar sobre um outro aspecto desta terceira mulher: a sua discrição. Ela é quase imperceptível, é a "que se esconde". E este aspecto conduziu-o a uma interpretação, a meu ver, incorrecta: a identificação da terceira mulher como sendo a deusa da morte, o que, na tríade das moirai gregas, faria com que a terceira fosse Atropos, a anunciadora fatal. Ora, foi já visto, o terceiro termo desta tríade dialéctica é Kloto, a fiandeira, a que faz a síntese entre as outras duas. Ela é também a mais discreta, a "que se esconde" (como foi possível ver pelos registos inquisitoriais e pelo folclore portugueses, bem como na mitologia vigente no resto da Europa), ela é a única que nunca se mostra aos mortais para lhe anunciar a sorte ou o infortúnio. Ela é, podia dizer-se, um puro conceito filosófico.

Mas o erro de Freud tem uma razão de ser. Com o devir, com o tempo, vem a morte. Sendo um termo sintético, a terceira moira engloba as outras duas dentro de si. Esta contradição reflecte-se na proposta do psicanalista, que afirma que "na nossa suposição, a terceira das irmãs é a deusa da morte, a própria morte. Mas no julgamento de Páris ela é a deusa do amor, no conto de Apuleio ela é alguém comparável à deusa pela sua beleza, no Mercador de Veneza ela é a mais justa e sábia das mulheres, no Rei Lear ela é a única filha leal". O autor concilia o amor e a morte, e justifica-se: "contradições de um certo tipo - subtituições pelo oposto - não oferecem dificuldades ao trabalho de interpretação analítica. Não iremos invocar aqui o facto de os contrários serem tão frequentemente representados por um só elemento nos modos de expressão usados pelo inconsciente, por exemplo nos sonhos. Mas convém lembrar que há forças motivadoras na vida mental que recorrem á substituição pelo oposto num processo que é conhecido como reacção-formação". Segundo o austríaco, este processo é uma forma de a mente humana exorcizar o medo da morte: "O homem, como sabemos, faz uso da sua actividade imaginativa, no sentido de satisfazer os desejos que a realidade não satisfaz. Assim, a sua imaginação rebela-se contra o reconhecimento da verdade corporizado no mito das moirai, e construiu em seu lugar uma derivação, na qual a deusa da morte foi substituída pela deusa do amor". 
Em suma, ao ignorar o papel simbólico da fiandeira, a mulher que constitui verdadeiramente o terceiro termo, Freud não conseguiu ver nas tríades referidas uma pura representação do movimento dialéctico, entregando o lugar da fiandeira à deusa da morte e, depois, identificando os dois opostos, amor (fortuna) e morte, atribuindo essa identificação a um processo de negação e substituição da realidade por parte da imaginação humana. Por outro lado, a insistência nos aspectos sexuais impediu-o de ver que a escolha entre três elementos, existentes em tantos contos e temas folclóricos, é muito mais do que a mera escolha de uma mulher, de um objecto de desejo. É a representação simbólica do destino humano.

Sobre esta hiper-acentuação do aspecto sexual, interessa voltar a um dos discípulos de Freud, Karl Abraham, para uma confrontação de um pequeno trecho seu com elementos retirados da pesquisa nos arquivos da Inquisição portuguesa. Refiro-me aos casos do parto místico e do elemento de possessão a eles associado. Escreveu Abraham que "desde tempos imemoriais, um certo número de objectos e de actividades parece ter sido colocada ao serviço da simbolização sexual. Encontramo-los, dotados desta significação, na Bíblia, nos Védas, nos mitos gregos e nórdicos, nos poemas de tempos históricos, nos sonhos. É assim com a serpente, como símbolo do membro viril”"65. Primeiro ponto a reter: os diversos ambientes culturais referidos podem ser agrupados em apenas dois: mundo semita (Bíblia) e mundo indo-europeu (Védas, Grécia, Escandinávia). Segundo ponto a reter: o primeiro existiu em íntima vizinhança com o segundo e foi por ele influenciado ${ }^{66}$.

Portugal pertence ao contexto indo-europeu e, como tal, partilha os seus símbolos. Atente-se no que é dito, ainda sobre o simbolismo da serpente, por Karl Abraham: "a serpente desempenha um papel importante nos sonhos das mulheres; a significação do símbolo é geralmente clara. O medo supersticioso das serpentes aparece ligado à mesma representação. Nós deparamo-nos frequentemente com doentes mentais, os quais alegam ser atacados por serpentes que se introduzem no seu sexo ou na sua boca.

\footnotetext{
${ }^{65}$ ABRAHAM, Karl - Psychanalyse..., cit., p. 21.

${ }^{66}$ Vejam-se, a título de exemplo, as pesquisas de mitologia comparada do assiriologista e egiptologista Robert Brown Junior, ainda no século XIX, referidas por DORSON, Richard M. - The eclipse of Solar Mythology. The Journal of American Folklore. 68 (1955) 408.
} 
Nós sabemos que, a este respeito, a boca não é mais do que um substituto da vulva (o "deslocamento para o alto" de Freud (...) ${ }^{67}$.

Referi acima o papel da serpente enquanto agente do mundo dos mortos e a forma como várias mulheres alegavam ser possuídas por uma cobra que lhes entrava pelo corpo, frequentemente pela boca. Num dos casos, uma ficou aliviada através do estado de êxtase, num outro revelou comportamentos de possessão e tinha que ser exorcizada depois de a cobra ter entrado no seu interior. Tudo isto é indicativo do carácter sobrenatural e espiritual da cobra. Acresce a tudo o simbolismo que o complexo xamânico eurasiático atribuía à serpente, como símbolo da alma. Veja-se, a propósito, o sonho, referido no Auto dos místicos, do rei burgundo Guntram, em que a alma sai do corpo do rei durante o sono (o êxtase), sob a forma de um pequeno réptil ${ }^{68}$. Por outro lado, nalguns casos de parto místico estudados, o animal que entra no corpo da mulher fecundada trata-se de uma pomba, não de uma serpente. É difícil ver na pomba um animal fálico. Num caso, ainda, trata-se de um feixe de luz que entra pela boca. Como tal, e não conhecendo em pormenor os casos referidos por Abraham, aquilo que este autor refere acerca de alguns "doentes mentais" parece apontar para um simbolismo ligado à possessão por espíritos de mortos, um aspecto homólogo dos casos de licantropia referidos acima, ou dos sonhos incubatórios. Três símbolos do "complexo totalizante simbólico": membrana amniótica, serpente, lobo. Lembre-se, a propósito, uma carta de Freud ao seu amigo Wilhelm Fliess, citada por Carlo Ginzburg, na qual o "pai da psicanálise” se confessa desconcertado ao referir as confissões obtidas pelos juízes da Inquisição: "porque é que as confissões extorquidas através de tortura são tão semelhantes ao que me dizem os pacientes em tratamento psicológico?"69. Na carta seguinte, enviada uma semana depois (24 de Janeiro de 1897), Freud nota que os comportamentos e confissões descritos obedecem a um padrão. As danças e o vôo das bruxas, os contactos com o diabo, todos estes elementos

${ }^{67}$ ABRAHAM, Karl - Psychanalyse..., cit., p. 21.

${ }^{68}$ RIBEIRO, António - O Auto dos místicos..., cit., p. 391.

${ }^{69}$ Ver FREUD, Sigmund - The origins of Psycho-analysis. Letters to Wilhelm Fliess, Drafts and Notes: 1887-1902. London: Imago, 1954, p. 188; a citação feita por Carlo Ginzburg aparece em GINZBURG, Carlo - Freud, o homem dos lobos e os lobisomens in GINZBURG, Carlo. Mitos, emblemas, sinais. São Paulo: Companhia das Letras, 1990, p. 212. 
apresentam uma estrutura comum. Onde Jung viu uma manifestação do inconsciente colectivo, Freud sugeriu, nessa mesma carta, "sobrevivências de um culto sexual primitivo, que no oriente semita pode ter sido, em tempos, uma religião". E desenvolve a ideia, levando a imaginação ao limite: "os actos de perversão sexual são sempre semelhantes, têm sempre um significado e são baseados num padrão que pode ser compreendido. Eu começo a sonhar com uma religião demoníaca extremamente primitiva cujos ritos continuam a ser executados sercretamente (...), os indícios são abundantes"70. Muito provavelmente, Freud estava, sem o saber, a falar do "complexo totalizante simbólico".

Uma última referência aos desvios provocados por este pan-sexualismo freudiano tem a ver com um dos mais famosos pacientes de Freud, o homem dos lobos. O texto sobre o caso, História de uma neurose infantil, foi brilhantemente dissecado por Carlo Ginzburg, mas um olhar à luz do "complexo totalizante simbólico" permitirá aprofundar um pouco mais o caso ${ }^{71}$.

O paciente, um russo pertencente a uma família abastada, tinha uma característica que o tornava especial: ter nascido no dia de Natal, envolto na membrana amniótica. Entre os três e cinco anos de idade, teve um sonho: "Sonhei que era de noite e que estava na minha cama. (A minha cama estava com os pés virados para uma janela; em frente da janela estava uma fila de velhas nogueiras. Eu sei que era Inverno quando tive o sonho, e era de noite). De repente, a janela abriu-se e eu fiquei aterrorizado ao ver que alguns lobos brancos estavam sentados na grande nogueira em frente à janela. Eram seis ou sete. Os lobos eram muito brancos e assemelhavam-se mais a raposas ou cães pastores, porque tinham grandes caudas como as raposas e as orelhas levantadas como os cães quando estão atentos a alguma coisa. Aterrorizado, evidentemente com receio de ser comido pelos lobos, gritei e acordei" ${ }^{\prime 2}$.

${ }^{70}$ Ver FREUD, Sigmund - The origins of Psycho-analysis..., cit., p. 189.

${ }^{71}$ Ver respectivamente FREUD, Sigmund - From the history of an infantile neurosis in The Standard Edition of the Complete Psychological Works of Sigmund Freud. London: Hogarth Press, 1973, vol. XVII (1917-1919). p. 7-103 e GINZBURG, Carlo - Freud, o homem dos lobos..., cit, p. 207-217.

${ }^{72}$ FREUD, Sigmund - From the history..., cit., p. 29. 
Ao estudar a abordagem do vienense ao caso do homem dos lobos, Ginzburg faz notar a forma como a vertente folclórica escapou a Freud, nomedamente os aspectos ligados ao nascimento do paciente. A circunstância de ter nascido na noite de Natal e envolto na membrana amniótica ligava-o ao mundo dos mortos. Assim, o historiador italiano pretendeu ver, correctamente do meu ponto de vista, "um sonho de carácter iniciático, induzido pelo ambiente cultural circundante" $"$. Mas, articulando o caso do paciente de Freud com o "complexo totalizante simbólico", temos uma correspondência perfeita. Atente-se num pormenor do sonho: "sei que era Inverno quando tive o sonho, e era de noite". Inverno e noite são facetas homólogas de toda esta mitologia dualista. Os elementos que lhe aparecem no sonho são lobos, que estão em cima de uma árvore. Aárvore é um símbolo sintético, como já referi atrás, faz a ligação entre o "alto" e o "baixo". É um veículo dos agentes do outro mundo para se manifestarem neste. Estes agentes têm também uma carga simbólica forte, são lobos. Finalmente, a questão da membrana amniótica, símbolo de ligação ao mundo subterrâneo e o facto de ter nascido na noite de Natal, coincidindo, de forma geral, com o solstício de Inverno. O paciente referiu que por causa de ter nascido envolto no âmnio se via a si próprio como especial e indestrutível ${ }^{74}$. Freud, todavia, interpretou, tal como já fizera para o tema das três moirai, como um processo de negação e substituição. Disse o pai da psicanálise que "tal pode ser traduzido da seguinte maneira: "a vida faz-me tão infeliz! Tenho que voltar para o útero!" 75 .

Sobre os símbolos referidos há duas questões pertinentes: qual a relação desses símbolos com a mente humana e qual o grau de universalidade dos mesmos? Que valor atribuir à partilha simbólica, à aceitação generalizada dos símbolos do "complexo totalizante simbólico"? Se se admitir que este complexo está na génese de comportamentos como a licantropia, que está disseminada por vastas regiões do globo, então teremos que nos interrogar sobre as razões que levaram a uma tal difusão. E aqui aproximamo-nos do conceito, desenvolvido por Jung, de "inconsciente colectivo". Por outro lado,

\footnotetext{
${ }^{73}$ GINZBURG, Carlo - Freud, o homem dos lobos..., cit, p. 210.

${ }^{74}$ FREUD, Sigmund - From the history..., cit., p. 99.

${ }^{75}$ FREUD, Sigmund - From the history..., cit., p. 100.
} 
há símbolos que parecem ter uma expansão mais alargada do que outros. A serpente, por exemplo, está muito mais difundida do que o tear. E que significado atribuir à persistência de esquemas ternários?

Importa ver para além dos símbolos. Em toda esta semiótica, assente na metáfora e na alegoria, existe uma forma de pensar polarizada em termos dualistas e cujo funcionamento se faz a três tempos. Ao expôr a sua Interpretação psicológica sobre o dogma da Trindade, Carl Gustav Jung demonstra que a génese do pensamento triádico sobre o qual se funda o dogma da Trindade tem antecedentes pré-cristãos ${ }^{76}$. Mais importante ainda: está disseminado por diferentes quadrantes geográficos e cronológicos, convidando a colocar a hipótese de uma homogeneidade de funcionamento do cérebro humano. Uma hipótese estruturalista que teria agradado a Lévi-Strauss. Falando do Timeu, a obra de Platão que Jung considera "a fonte imediata das concepções trinitárias do pensamento grego", o investigador suíço afirma que "embora seja sumamente improvável que a Trindade cristã provenha da trindade do Timeu, trata-se do mesmo arquétipo"77. Jung explica esta pulverização recorrendo aos arquétipos existentes na psique humana. E o conceito de arquétipo não foi algo estático, tem uma história no interior do pensamento de Jung.

Jung terá ficado surpreendido quando começou a detectar nos seus pacientes resíduos de imagens de religiões e mitos arcaicos, os quais estes não teriam qualquer possibilidade de conhecer conscientemente ${ }^{78}$. Ao desenvolver esta ideia, Jung criou a figura das imagens arcaicas, as quais, à medida que a sua pesquisa evoluía, começou a substituir pela figura do arquétipo. A diferença entre as duas, como referiu Raymond Hostie, é que "a imagem arcaica é a forma simbólica sob a qual o arquétipo aflora a consciência; o arquétipo, ele próprio, é a disposição inconsciente e colectiva como tal"79. E que disposição é essa? Se a imagem arcaica se objectiva em imagens e símbolos, o arquétipo é "um elemento puramente formal, 1979.

${ }^{76}$ JUNG, Carl G. - Interpretação psicológica do dogma da Trindade. Petrópolis: Vozes,

${ }_{77}$ JUNG, Carl G. - Interpretação..., cit., p. 8 e 75 respectivamente.

${ }^{78}$ HOSTIE, Raymond - Du Mythe a la Religion. La Psychologie Analytique de C. G. Jung. Bruges: Desclée de Brouwer, 1955, p. 51

${ }^{79}$ HOSTIE, Raymond - Du Mythe..., cit., p. 57. 
uma facultas praeformandi, uma possibilidade de representações dadas à priori" ${ }^{80}$. Aproximamo-nos aqui bastante da ideia exposta no complexo totalizante simbólico, dissecado ao longo deste texto. O pensamento triádico que expus é, também ele, puramente formal, e também ele não é percebido de forma consciente. A forma como ele se objectiva é através de símbolos. Só que, neste ponto, Jung não fala num arquétipo mas em "arquétipos". Ele não reconhece a estrutura triádica como sendo "o arquétipo", mas fala de uma multiplicidade. Na religião, como afirmou Luis Maldonado, aplicando a perspectiva do investigador suíço à religiosidade popular, "temas como a terra-mãe, a vida a nascer da morte, a regeneração pela volta às origens, a união de contrários, o Deus-criança, podem parecer "arquétipos", ou seja, constantes de tipo simbólico que subjazem impressas em todos os homens de qualquer época"\$1. Mas, vendo com atenção, todas estas formas "simbólicas" se podem reduzir à luta dialéctica dos opostos. Maldonado parece estar a falar mais de imagens arcaicas, da objectivação através do símbolo, do que propriamente, de um conceito formal. Acerca da teoria do incesto, no qual Jung recolheu, apesar de tudo, imensos elementos formulados por Freud, afirma aquele que "o problema psico-patológico do incesto é a forma natural mal-entendida da união dos opostos, a qual como problema psíquico ainda nunca se tornou consciente, ou se já esteve consciente alguma vez, tornou a escapar do alcance da consciência" ${ }^{\text {"2 }}$. Jung reconhece que há um fundo dialéctico e até simbólico na questão do incesto, mas coloca o assunto ainda em termos de recalcamento e de patologia, adoptando a perspectiva de Freud. Este, por sua vez, baseou a sua teoria no mito de Édipo e no facto de haver tantos mitos baseados no assunto, descartando o aspecto simbólico e remetendo todo o assunto para o desejo sexual reprimido.

Em síntese, o conceito jungiano de arquétipo parece convergir para a proposta deste texto acerca do "complexo totalizante simbólico". Contudo, na perspectiva do psicólogo suíço, este complexo surge pulverizado e composto por "pequenos arquétipos" que são, na minha perspectiva, apenas

\footnotetext{
${ }^{80}$ HOSTIE, Raymond - Du Mythe..., cit., p. 59.

${ }^{81}$ MALDONADO. Luis - Religiosidad Popular. Nostalgia de lo magico. Madrid: Ediciones Cristianidad, 1975, p. 116.

82 JUNG, Karl. G. - “Mysterium Conjunctionis”. Pesquisas sobre a separação dos opostos psíquicos na alquimia. Petrópolis: Vozes, 1985, p. 88.
} 
expressões fragmentárias do "complexo totalizante simbólico" objectivadas através de símbolos. Jung definiu, a meu ver correctamente, o símbolo como um "mediador", que faz a ligação do indivíduo consigo próprio, com a colectividade e com o $\operatorname{cosmos}^{83}$. Se Freud via no símbolo apenas um disfarce com que os desejos reprimidos surgiam perante a consciência, em que apenas o que estava escondido por detrás do símbolo interessava, Jung vai afirmar a importância dos símbolos como reveladores de uma dialéctica entre o consciente e o inconsciente ${ }^{84}$.

De alguma forma isto reflecte o que tem sido dito acerca do complexo totalizante simbólico. Uma forma dialéctica de pensar o real que, enquanto elemento puramente formal, reside apenas no inconsciente e que, para que se possa concretizar, necessita de tomar como símbolos elementos do mundo físico. Surgem assim o lobo, a serpente, a árvore, o tear, etc. Há a considerar, ainda, um espinhoso problema de cariz epistemológico. A divisão tripartida de matriz dialética é a única forma de pensar o absoluto. Mas ela está na natureza íntima das coisas ou é apenas uma forma de pensar? A dialéctica está na natureza íntima do real, físico e metafísico. O cérebro humano apreende essa realidade mas, não o conseguindo exprimir pela linguagem, projecta essa realidade em objectos familiares. Nasce assim o símbolo. E assim, tal como na cura xamânica ou na psicanálise, o homem interage com o mundo simbólico como representação da sua inter-acção com realidades inenarráveis ${ }^{85}$.

Um último aspecto. A questão da universalidade destes símbolos. Quer Lévi-Strauss quer Jung adoptaram uma perspectiva estruturalista, postulando que as semelhanças entre espaços geográficos e culturais homogéneos se devem a uma estrutura universal do cérebro humano. Sobre o assunto irei apenas aludir a um conjunto de dados que expus na minha dissertação e que poderão ser um contributo para a compreensão do assunto.

${ }^{83}$ STAUDE, John Raphael - From Depth Psychology to Depth Sociology: Freud, Jung and Lévi-Strauss. Theory and Society. 3 (1976) 318.

${ }^{84}$ HOSTIE, Raymond - Du Mythe..., cit., p. 37-48.

${ }^{85}$ Como referiu Cassirer, "nenhum processo mental chega a captar a realidade em si, já que, para poder representá-la, para poder, de algum modo, retê-la, tem de socorrer-se do signo, do símbolo. E todo o simbolismo esconde em si o estigma da mediatez, o que o obriga a encobrir quanto pretende manifestar", ver CASSIRER, Ernst - Linguagem, mito e religião. Porto: Edições RES, 1976, p. 14. 
Não deixará, contudo, de ser uma abordagem superficial. A questão necessita de uma longa e árdua pesquisa futura.

No Auto dos místicos tive a oportunidade de estabelecer um paralelismo entre a religiosidade popular portuguesa e um conceito que, devo reconhecer, permaneceu sempre algo vago e difuso ao longo do meu trabalho e que fui definindo alternadamente como "mundo indo-europeu" ou "xamanismo eurasiático". Parece-me que esta última definição se adequa melhor. Os dois conceitos têm, apesar de tudo, pontos de contacto que não irei explorar em detalhe. Dou apenas um exemplo. No xamanismo há uma clara vertente dialéctica e de luta de opostos. No mundo indo-europeu há uma divisão tripartida da sociedade que, tentei demonstrar na minha tese, se baseia na luta de opostos, uma perspectiva que terá escapado a Georges Dumézil. Outro elemento: o gnosticismo e maniqueismo tiveram o seu berço no mundo indo-iraniano e na vizinhança do mundo semita, contaminando-o ${ }^{86}$. Mais ainda, o xamanismo e a visão tripartida aparecem em contextos não indo-europeus, mas onde é admissível uma iinfluência directa em face da proximidade territorial, como a China por exemplo ${ }^{87}$. Sintetizando tudo isto, toda esta cosmovisão surge entre os povos indo-europeus mas não se esgota, longe disso, neles. Por outro lado, embora o assunto não seja pacífico, há uma região que parece ligada ao seu aparecimento, e ela coincide, de forma geral, com a estepe da Ásia Central. Esta funciona como uma ponte entre a Europa e a América.

Como já referi, o assunto necessita de uma pesquisa mais profunda. No entanto, a possibilidade de difusão geográfica desta cosmovisão, ao longo de períodos muito extensos, a partir de um ponto original - uma visão histórica, portanto - pode ser uma boa alternativa á visão estruturalista, para a qual o ponto original é sempre a universalidade do funcionamento do cérebro. Mas esta, reafirme-se, é ainda uma mera hipótese.

${ }^{86}$ Veja-se a propósito as palavras de Geo Widengren: “as concepções gnósticas que aparecem no maniqueismo têm um fundo não apenas iraniano, mas também indo-iraniano. Isto é o que sempre afirmou Reitzenstein e as suas ideias vão-se confirmando cada vez mais", WIDENGREN, Geo - Fenomenologia ..., cit., p. 448.

${ }^{87}$ Ver HARRELL, Stevan - The Concept of Soul in Chinese Folk Religion. The Journal of Asian Studies. 38 (1979) 519-528. 